Perinatology pISSN'2508-4887 • elSSN 2508-4895
Case report

Perinatology Vol. 31, No. 4, December, 2020 https://doi.org/10.14734/PN.2020.31.4.231

\title{
Hepatic Subcapsular Hematoma with Different Clinical Features in Two Neonates
}

\section{Yoonkyo Oh, MD, Gina Lim, MD, \\ Ki Won Oh, MD}

Department of Pediatrics, Ulsan University Hospital, University of Ulsan College of Medicine, Ulsan, Korea

Received: 4 May 2020

Revised: 30 June 2020

Accepted: 13 August 2020

Correspondence to

Ki Won Oh, MD

Department of Pediatrics, Ulsan

University Hospital, University of

Ulsan College of Medicine, 877

Bangeojinsunhwando-ro, Dong-gu,

Ulsan 44033, Korea

Tel: +82-52-250-8861

Fax: +82-52-250-8071

E-mail: pentawish@hanmail.net

Copyright@ 2020 by The Korean Society of Perinatology

This is an Open Access article distributed under the terms of the Creative Commons Attribution Non-Commercial License (http://creativecommons.org/ license/by-nc/4.0/), which permits unrestricted non-commercial use, distribution, and reproduction in any medium, provided that the original work is properly cited.
The liver of a newborn is vulnerable to damage during the process of delivery or on external manipulation. Although hepatic subcapsular hematoma occurs relatively commonly in the perinatal period, it is clinically unnoticeable in the majority of the cases. We report two cases of hepatic subcapsular hematoma in neonates who presented with different clinical features. The first newborn was a macrosomic full-term infant. He presented with severe hyperbilirubinemia, requiring intensive phototherapy and exchange transfusion twice within 8 days of life. In contrast, the other baby was a very lowbirth-weight preterm infant, resuscitated with endotracheal intubation and chest compression due to asphyxia. He presented with severe pallor, uncontrolled bleeding tendency, and hemorrhagic shock which suddenly lead to catastrophic result. Identifying the high-risk patients and various clinical characteristics is crucial for the early detection and proper management of hepatic subcapsular hematoma in newborns.

Key Words: Hematoma , Liver, Jaundice, Hemorrhagic shock

서론

신생아의 간은 분만 과정이나 외부 압박에 의해 손상 받기 쉬운 장기로, 간피막하혈종은 부검에서는 비교적 흔히 발견되나 대개는 크기가 작고 무증상인 경우가 많아 임상적으로 경 험하는 경우는 드물다. ${ }^{1-4}$ 간피막하혈종의 발생과 관련된 위험인자로는 산모, 신생아, 산과 적 측면에서 다양한 요인들이 있으며, ${ }^{5}$ 최근에는 과체중아나 둔위 분만 과정 또는 아픈 미숙 아에서 주로 발생하는 것으로 보고되고 있다. ${ }^{1-5}$ 저자들은 심한 황달을 주소로 전원된 만삭 아와 신생아 가사로 인해 소생술을 시행받고 전원된 미숙아에서 발생한 간피막하혈종을 경 험하였기에 보고하는 바이다.

\section{증례}

\section{1. 증례 1 \\ 환아: 생후 8일, 남아 \\ 주소: 황달}

출생력 및 현병력: 환아는 재태 연령 39 주 6 일, 출생 체중 $4,320 \mathrm{~g}$ 으로 자연분만을 통해 타원에서 출생하였으며, Apgar 점수는 1 분 8 점, 5 분 9점이었다. 출생 당시 특별한 문제는 없었으며, 신생아 출혈 질환을 예방하기 위해 출생 직후 비타민K $1 \mathrm{mg}$ 을 투여하였다. 생후 7 일째 육안적으로 황달이 관찰되어 시행한 검사에서 혈청 총 빌리루빈이 $19.6 \mathrm{mg} / \mathrm{dL}$ 로 증 가되어 광선 치료를 시작하였다. 생후 8일째 광선 치료에도 불구하고 두 시간 간격으로 시행 한 추적 검사에서 혈청 총 빌리루빈 수치가 각각 $22.0 \mathrm{mg} / \mathrm{dL}, 26.6 \mathrm{mg} / \mathrm{dL}$ 로 증가하여 본원 으로 전원되었다.

산모력 및 가족력: 산모는 37세 경산모로 혈액형은 Rh 양성 A형이었고, 임신 중 사고로 인 한 손상이나 임신성 고혈압, 당뇨병 등을 포함한 특정 질환에 이환된 특이 병력은 없었다. 가 
족력상 대사 질환을 포함하여 특이 사항은 없었다.

진찰 소견: 출생시 체중과 신장은 각각 $4,320 \mathrm{~g}, 53 \mathrm{~cm}$ 로 모두 90 백분위수 이상이었으며, 입원 당시 활력 징후는 혈압 94/63 $\mathrm{mmHg}$, 심박수 162 회/분, 호흡수 54 회/분, 체온 $36.7^{\circ} \mathrm{C}$ 로 안정 적이었다. 신체 진찰에서 무를 아래 쪽까지 황달 소견이 관찰되 었으며 두혈종이나 피부에 멍은 관찰되지 않았다. 흉부 청진에 서 양측 호흡음은 잘 들렸으며 심잡음은 들리지 않았다. 복부 진 찰에서 간비종대 및 복강내 종괴는 촉지되지 않았다.

검사 소견 및 치료: 입원 당일 시행한 말초 혈액 검사상 혈색 소 $11 \mathrm{~g} / \mathrm{dL}$, 적혈구 용적률(hematocrit) $32.2 \%$, 백혈구 수 22,650/ $\mu \mathrm{L}$, 혈소판 $183,000 / \mu \mathrm{L}$, 망상적혈구 수 $5.6 \%$ 였으며, 혈액형은 Rh 양성 A형이었다. 생화학 검사에서 aspartate aminotransferase (AST) 57 IU/L, alanine aminotransferase (ALT) 43 IU/L이었고, 혈청 총 빌리루빈 수치는 $31.7 \mathrm{mg} / \mathrm{dL}$, 직접 빌리루빈 수치는 $2.2 \mathrm{mg} / \mathrm{dL}$ 로 상승되어 있었다. 말초혈액 도말 검사에서는 적혈 구는 정구성, 정색소성이었고, 용혈을 시사하는 소견은 없었다. Coombs 검사는 모두 음성이었으며, 혈액응고 검사는 프로트롬 빈시간(prothrombin time) 10.7초(정상 범위: 10-16초), 활성 화 부분 트롬보플라스틴 시간(activated partial thromboplastin time) 30.3초(정상 범위: 31-54초)로 정상이었다.

입원 당일 집중 광선 치료와 교환수혈을 시행하였으며, 교환 수혈 후 혈청 총 빌리루빈 수치는 $23.8 \mathrm{mg} / \mathrm{dL}$ 로 감소하였다. 하 지만 12 시간 후 시행한 추적 검사에서 혈청 총 빌리루빈 수치가 $28.9 \mathrm{mg} / \mathrm{dL}$ 로 다시 상승하여 두 번째 교환수혈을 시행하였으 며, 이후 $19.8 \mathrm{mg} / \mathrm{dL}$ 로 호전되었다(Fig. 1). 입원 2일째 내출혈 을 확인하기 위해 시행한 복부 초음파 검사에서 다수의 격막을 가진 경계가 명확한 낭성 종괴가 관찰되었으며(Fig. 2A), 간피 막하혈종, 낭성 중간엽 과오종과 같은 간종양 또는 간농양 등과 의 감별을 필요로 하였다. 당시 시행하였던 알파태아단백 수치
는 $14,151 \mathrm{ng} / \mathrm{mL}$ 로 높게 측정되었으나 환아가 신생아임을 고 려했을 때 정상 범위 $(33,113 \pm 32,503 \mathrm{ng} / \mathrm{mL})$ 에 해당하였다. 추 가로 복부 전산화단층촬영 검사를 시행하였고 검사 결과 간 우 엽에 $6.2 \times 2.7 \mathrm{~cm}$ 크기의 경계가 명확한 고밀도 혈종이 관찰되 었다(Fig. 2B). 혈종이 간 캡슐 내에 국한되어 있고 환아의 활력 징후가 안정적이어서 집중 광선 치료를 유지하며 경과 관찰을 계획하였다. 입원 5 일째 시행한 추적 검사 결과 혈청 총 빌리루 빈 수치가 $9.6 \mathrm{mg} / \mathrm{dL}$, 직접 빌리루빈 수치는 $0.9 \mathrm{mg} / \mathrm{dL}$ 으로 호 전되어 광선 치료를 중단하였으며, 입원 6 일째 시행한 복부 초 음파 검사에서 혈종의 크기가 감소되어 퇴원하였다. 외래에서 생후 3 개월 및 9 개월경 추적 초음파 검사를 시행하였으며 합병 증 없이 호전됨을 확인하였다(Fig. 2C).

\section{2. 증례 2}

환아: 생후 1 일, 남아

주소: 신생아 가사

출생력 및 현병력: 재태연령 30 주 5 일, 체중 $1,300 \mathrm{~g}$, 태아곤 란으로 응급 제왕절개술을 통해 타원에서 출생한 환아로 Apgar 점수는 1 분 3 점, 5 분 3 점, 10 분 5 점이었다. 출생 직후 자가 호흡 이 없고 심박수가 60회/분 미만이어서 기관 내 삽관 및 흉부 압 박을 시행하면서 본원으로 전원되었다.

산모력 및 가족력: 산모는 30세 초산모로 2회 유산 병력이 있 었고, 임신성 고혈압, 혈소판 이상 질환이나 혈액응고장애와 같 은 기저 질환은 없었다. 가족력상 유전 질환을 포함하여 특이 사 항은 없었고, 타 병원에서 시행한 산전 초음파 검사에서 이상 소 견은 발견되지 않았다.

진찰 소견: 출생시 체중 $1,300 \mathrm{~g}$ (25백분위수), 신장은 $40 \mathrm{~cm}$ (50백분위수)였다. 입원 당시 활력 징후는 혈압 $48 / 21 \mathrm{mmHg}$, 심박수 50회/분, 자가호흡은 없었으며, 산소포화도는 $60 \%$ 로 확

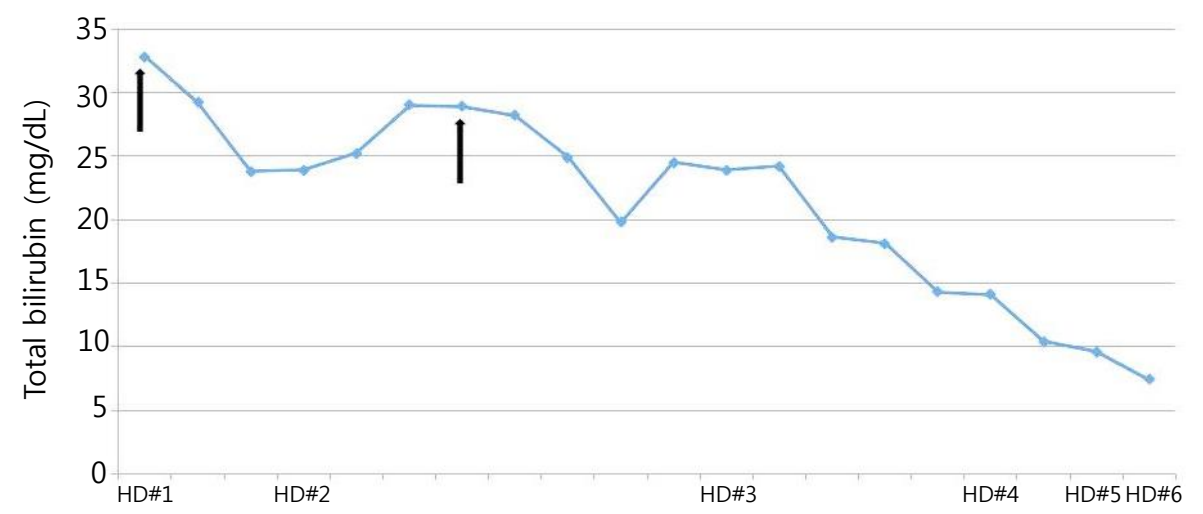

Fig. 1. Changes in serum total bilirubin levels during hospitalization in case 1 are plotted over time. The time of exchange transfusion is denoted by the black arrow. HD, hospital day. 
인되었다. 15 분간 심폐소생술을 시행하였으며, 기관 내 튜브를 통해 에피네프린을 투여한 후 심박수는 100회/분으로 회복되 었고, 제대정맥 카테터를 삽관 후 승압제를 지속적으로 투여하 였다. 신체진찰에서 간비종대 및 복부 종괴는 만져지지 않았다.

검사 소견 및 치료: 입원 당시 시행한 말초혈액 검사에서 혈 색소 $19.7 \mathrm{~g} / \mathrm{dL}$, 적혈구용적률 $67.3 \%$ 백혈구 수 $9,080 / \mathrm{LL}$, 혈 소판 $68,000 / \mu \mathrm{L}$ 이었다. 일반 생화학 검사 중 간기능 검사에서 AST 1,965 IU/L, ALT 179 IU/L로 증가되어 있었으며, 혈액요 소질소 $21.3 \mathrm{mg} / \mathrm{dL}$, 크레아티닌은 $1.3 \mathrm{mg} / \mathrm{dL}$ 이었다. 혈액응고 검사에 프로트롬빈시간, 36.3초 international normalized ratio (INR) 3.72 (정상 범위: 0.8-1.2), 활성화 부분 트롬보플라스틴 시간 180초 초과(정상 범위: $31-54$ 초)로 지연된 소견을 보여 비 타민K 투여 및 신선동결혈장을 수혈하였다. 혈 액가스 검사에서 $\mathrm{pH}$ 6.6, $\mathrm{PCO}_{2} 25 \mathrm{mmHg}, \mathrm{HCO}_{3}{ }^{-} 2.4 \mathrm{mEq} / \mathrm{L}$ 로 심한 대사성 산 증을 보였으며 급성 저혈압 상태를 보여 수액 요법과 승압제 치 료를 시행하였다. 입원 2일째 환아는 창백하게 보였으며 시행한 추적 검사에서 혈색소수치 $6.0 \mathrm{~g} / \mathrm{dL}$, 적혈구용적률 $19.2 \%$ 로 급
격히 감소하여 농축적혈구를 반복 수혈하였다. 급격한 혈색소 수치 감소로 시행한 뇌초음파상에서 뇌실내 및 뇌내 출혈의 소 견은 관찰되지 않았다. 입원 3일째 복부 팽만이 관찰되어 시행 한 복부 초음파 검사에서 다량의 복수와 우측 간 주위에 혈종이 관찰되었으며, 복부 전산화단층촬영에서 간피막하혈종 및 복강 내 출혈이 관찰되었다(Fig. 3). 수술적 치료에 관하여 고려하였 으나, 환아의 활력 징후가 불안정하고 혈액응고장애가 지속되 는 상태여서 보존적 치료를 통해 우선적으로 교정하고자 하였 다. 하지만 반복적인 성분수혈 중 환아의 상태가 급격히 악화되 어 입원 3일째 사망하였다.

\section{고찰}

간은 분만 과정에서 가장 흔히 손상되는 복강 내 장기 중 하나 로, 손상 시 주로 피막하혈종의 형태로 나타난다. ${ }^{6}$ 주산기에 사 망한 환아들을 대상으로 시행한 부검을 통한 연구들에 따르면

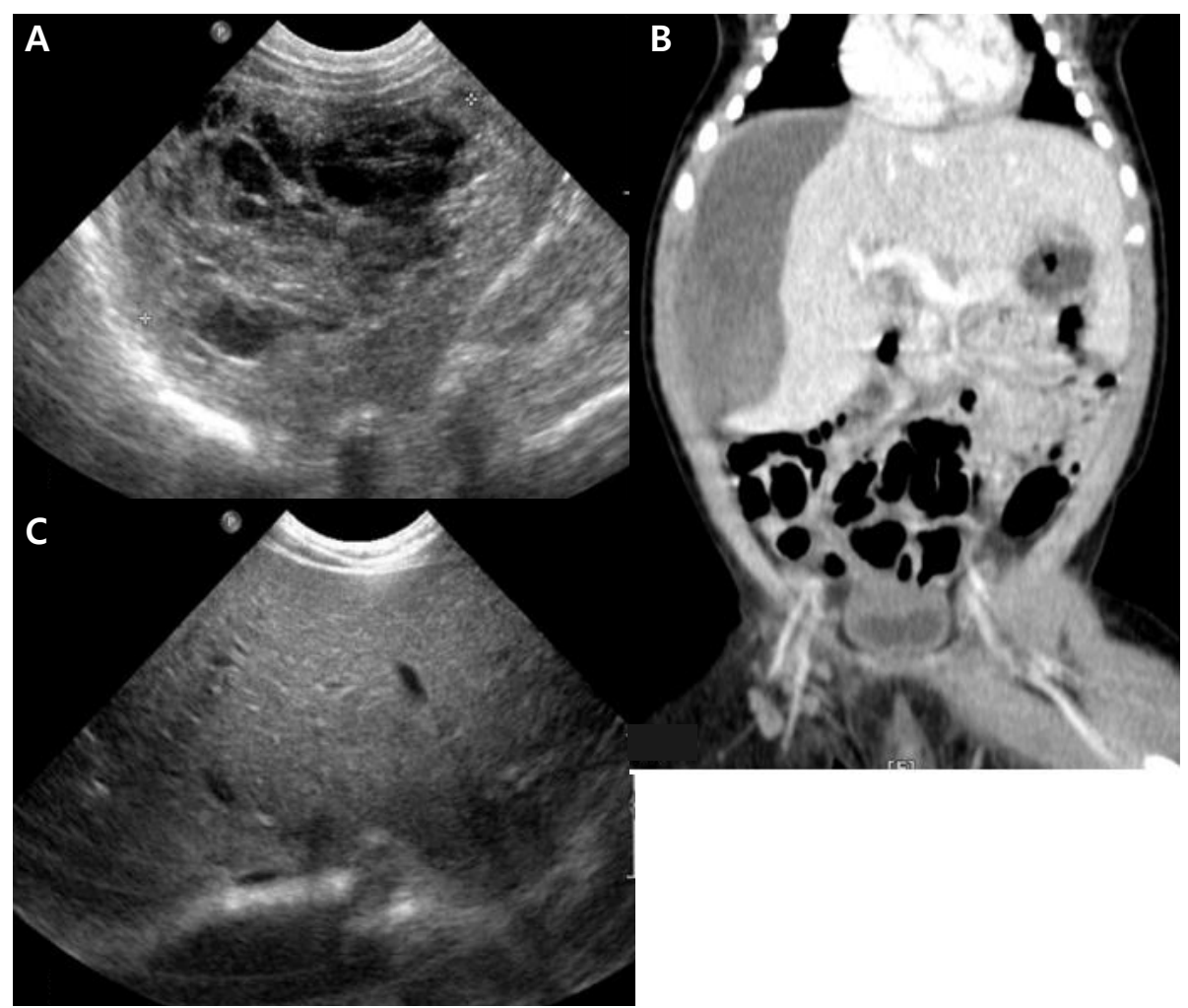

Fig. 2. Abdominal ultrasonography and computed tomography in case 1. (A) Initial abdominal ultrasonographic image shows a predominantly cystic septated mass with heterogeneous echotexture in the right lobe of the liver. (B) Abdominal computed tomography image shows massive well-encapsulated fluid collection in the subcapsular portion of the right lobe of the liver. (C) Follow-up abdominal ultrasonographic image, checked 9 months later, shows regression of the subcapsular hematoma. 


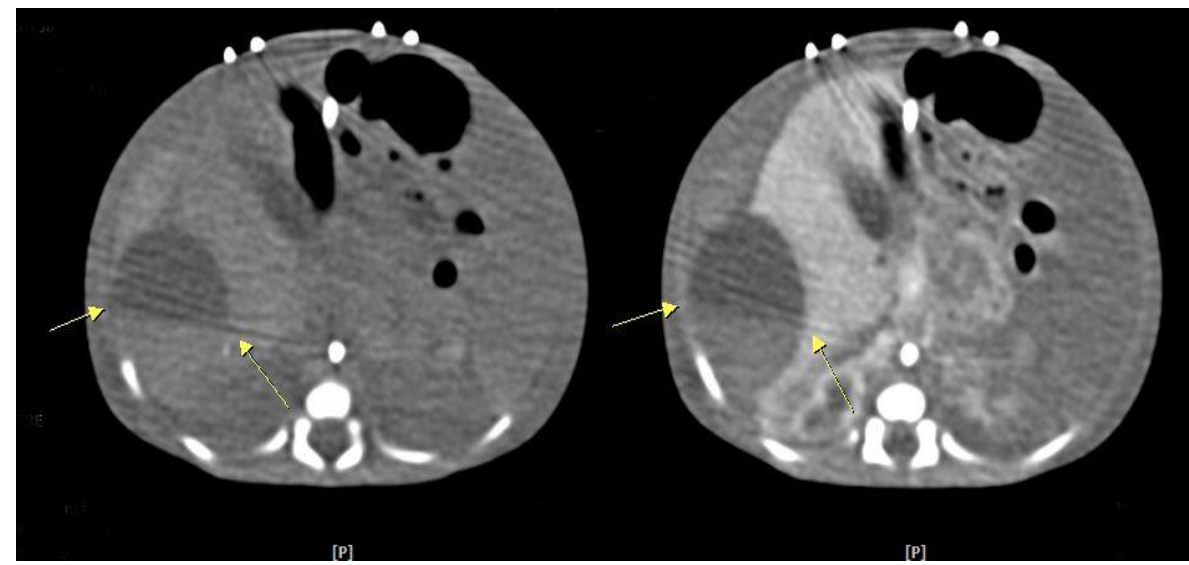

Fig. 3. Pre- and post-contrast abdominal computed tomography images in case 2 show a hypodense lesion, localized in the subcapsular zone of the liver, with fluid-fluid level (arrow) and large volume of ascites, suggesting hemorrhage.

대상군의 6.9-15\%에서 간피막하혈종이 발견되는 것으로 보고 된 바 있다. ${ }^{1-4}$ 하지만 발견된 간피막하혈종의 과반수 이상은 직 경의 크기가 $1 \mathrm{~cm}$ 미만으로 크기가 작으며, 무증상인 경우가 많 은 점을 고려할 때 실제 발생률을 가늠하기에는 어려움이 있으 며, 임상의로서 경험하는 경우는 비교적 드물다.

신생아의 간피막하혈종은 과거에는 비타민K 부족으로 인한 신생아 출혈성 질환과 관련되어 발생한 경우가 많았으나, 최근 에는 과체중아나 둔위 분만 과정에서 발생하는 분만 손상으로 인해 발생하거나 극소 저체중 출생아를 포함한 아픈 미숙아에 서 주로 발생하는 것으로 알려져 있다. ${ }^{1-5}$ 그 외에 산모의 외상, 임신 중독증, 저산소증, 혈액응고장애, 패혈증, 기흉, 소생술, 제 대 정맥관 삽입 등과의 연관성도 보고된 바 있다. ${ }^{1-10}$ 저자들의 증례 1 에서는 환아가 과체중아인 점을 고려할 때 분만 과정 중 인지하지 못한 손상으로 인해 간피막하혈종이 발생하였을 가능 성이 높으며, 증례 2에서는 극소 저체중 출생아, 미숙아, 신생아 가사로 인한 저산소증, 혈액응고장애, 흉부 압박을 포함한 소생 술과 제대 정맥관 삽입술 등과 같은 다양한 위험 요인이 작용하 였을 것으로 판단된다. 특히 소생술 도중 시행되는 흉부 압박의 경우 간에 연결된 관상인대와 같은 다양한 인대의 과신전을 일 으킴으로써 간에 열상이 발생하여 출혈을 유발할 수 있는 것으 로 알려져 있다. ${ }^{2}$

간피막하혈종의 임상 증상은 손상 정도에 따른 출혈의 양과 속도에 따라 다양하게 나타날 수 있다. 따라서 임상의는 간피막 하혈종이 발생할 수 있는 여러 위험 인자와 더불어 이로 인해 발 생할 수 있는 다양한 임상 증상을 인지하여 신속한 진단이 이루 어질 수 있도록 하는 것이 무엇보다 중요하다. 간피막하혈종은 대체로 크기가 4-5 cm 가량 증가된 이후 복강 내로 파열이 일 어나는 것으로 알려져 있다. 따라서 서서히 진행하는 출혈의 경
우 손상 후 1-3일 동안은 특별한 증상이 나타나지 않을 수 있으 며, 드물게는 저자들의 증례 1 과 같이 1 주일 이상 지연되는 경 우도 있다. ${ }^{8}$ 주로 창백함, 황달, 보챔, 호흡 곤란 등의 증상을 보 이며, $2,5,8,10,11$ 때로는 복강 내로 파열이 발생한 경우 음낭의 색조 변화가 관찰되어 이에 대한 원인 규명을 위한 검사 도중 우연히 발견되는 경우도 있다. ${ }^{12}$ 또한 우상복부 종괴로 촉진될 수 있으 며 이러한 경우 신생아기에 발생 가능한 간에서 기원하는 종양 과의 감별을 필요로 한다. ${ }^{7,13,14}$ 반면에 급격하게 많은 양의 출혈 이 단기간에 발생하는 경우 출생 후 초기부터 혈량 저하에 따른 증상과 출혈성 쇼크가 나타날 수 있다. ${ }^{1-5}$ 저자들의 증례 1 에서 는 생후 8 일째 2차례의 교환수혈을 필요로 할 만큼 심각한 황 달이 발생하였는데, 황달의 발생 시기, 산모와 환아의 혈액형, Coombs 검사 결과 등을 고려할 때 혈액형 부적합증으로 인한 황달의 가능성은 낮은 것으로 판단되었다. 따라서 내출혈의 원 인을 찾기 위해 복부 초음파 검사를 시행하였고 이를 통해 간피 막하혈종을 진단을 할 수 있었다. Son 등 ${ }^{11}$ 도 교환수혈을 필요 로 하는 심한 고빌리루빈혈증을 보인 신생아에서 간피막하혈종 을 발견한 증례를 보고한 바 있으나 이들의 연구에서는 간피막 하혈종과 더불어 부신 출혈이 동반되어 있었다. 반면 증례 2의 경우는 극소 저체중 출생 미숙아에서 신생아 가사로 인해 다발 성 장기 부전 및 파종혈관내응고 증후군이 동반된 상태에서 간 피막하혈종이 복강 내로 파열됨에 따라 많은 양의 출혈이 빠른 속도로 진행되어 일련의 증상이 나타난 것으로 판단된다.

간피막하혈종은 복부 단순촬영, 초음파, 전산화단층챨영 등 의 영상 검사를 통해 진단할 수 있다. 복부 단순촬영에서는 간비 대, 비위관이나 제대 정맥 관의 위치 이상, 복강내 비정상 유체 를 시사하는 음영 등이 보일 때 의심할 수 있으며, 초음파 검사 에서는 대부분의 간을 대체하여 차지하고 있는 저에코성 덩이 
의 형태 또는 간실질과 횡경막 사이에 저에코성 밴드의 형태로 발견된다. 하지만 이러한 영상 소견은 비특이적인 경우가 많아 간농양이나 간종양 등과 같은 다른 병변과의 감별을 필요로 한 다. ${ }^{7,9,13,15}$ 이를 위해 전산화단층촬영이나 자기공명영상검사를 추가로 시행해 볼 수 있으며, 반복적인 추적 초음파 검사를 통해 병변의 변화를 관찰하는 것이 감별 진단에 유용한 것으로 알려 져 있다. ${ }^{7,9,13,15}$ 저자들의 증례 1 에서도 초음파 검사에서 피막하 혈종 외에 낭성 중간엽 과오종과 같은 간종양, 완화 과정의 간농 양과의 감별이 필요한 소견이었으며, 반복적인 추적 초음파 검 사에서 피막하혈종이 흡수되면서 병변의 크기가 작아지는 것을 확인함으로써 진단에 도움을 얻을 수 있었다. 한편, 큰 소아나 성인의 경우 간의 양성 질환과 원발성 간종양의 감별에 알파태 아단백 수치가 유용하게 사용될 수 있으나 신생아 시기에는 알 파태아단백 수치의 정상 범위가 너무 광범위하여 진단적 가치 가 감소한다. 증례 1 의 경우에도 알파태아단백 수치가 14,151 $\mathrm{ng} / \mathrm{mL}$ 로 큰 소아나 성인의 정상치에 비해 월등히 높은 수치이 나신생아 시기를 고려할 때 정상 범위에 속하였다.

간피막하혈종의 치료에서는 환아의 임상 상태를 바탕으로 적절히 대처하는 것이 중요하다. 파열되지 않은 간피막하혈종 은 대부분 보존적 치료로 안정이 되는 경우가 많다. ${ }^{6,16}$ 보존적 치료로 출혈이 조절될 수 있다면 복막을 통해 혈액이 잘 흡수되 기 때문에 수술적 치료에 비해 더 나은 예후를 보일 수 있다. ${ }^{6,16}$ 다만 저자들의 증례 1 과 Son 등 ${ }^{11}$ 의 증례와 같이 신생아 시기에 황달이 심한 경우에는 영구적인 뇌손상을 유발할 수 있는 핵황 달이 발생할 수 있으므로 황달의 치료 방침에 따라 집중 광선 치 료와 함께 필요시 교환수혈을 통해 교정해 주어야 한다. 간피막 하혈종에 대한 수술적 치료는 수술시 지혈이 완벽하게 이루어 지기 어려운 경우가 많아 논란의 여지가 있다. 따라서 보존적 치 료에도 불구하고 빈혈과 쇼크가 호전이 없는 경우에 한하여 수 술적 치료가 권고된다. ${ }^{6,16}$ 증례 2 와 같이 간피막하혈종이 파열 되는 경우 복강 내 출혈을 야기하여 사망률이 높은 것으로 알려 져 있다. Mouzard 등 ${ }^{17}$ 의 연구에 따르면, 간피막하혈종의 복강 내 파열이 있었던 16 명의 환아 중 보존적 치료를 받았던 11 명 중 7 명과 수술적 치료를 받았던 5 명 중 2 명이 사망한 것으로 보고 하였다. 따라서 복강 내 파열이 발생한 경우 빈혈, 저혈량성 쇼 크 및 응고 장애를 교정하면서 소아 외과의와 상의하여 적절한 시기에 수술적 치료를 하는 것이 생존율을 높일 것으로 판단된 다. ${ }^{8}$ 본 증례들을 통해 신생아에서 발생한 간피막하혈종은 다양 한 임상 양상을 보일 수 있으며, 복강 내로 파열시 사망에 이를 수 있으므로 분만 손상이 발생하기 쉬운 난산이나 아픈 미숙아 와 같이 간손상이 발생하기 쉬운 고위험군에 대한 세심한 주의 가 필요하겠다.

\section{Conflict of interest}

No potential conflict of interest relevant to this article was reported.

\section{References}

1) French $C E$, Waldstein G. Subcapsular hemorrhage of the liver in the newborn. Pediatrics 1982;69:204-8.

2) Ryan CA, Finer NN. Subcapsular hematoma of the liver in infants of very low birth weight. CMAJ 1987;136:1265-9.

3) Shankaran S, Elias E, llagan N. Subcapsular hemorrhage of the liver in the very low birthweight neonate. Acta Paediatr Scand 1991;80:616-9.

4) Singer DB, Neave C, Oyer CE, Pinar H. Hepatic subcapsular hematomas in fetuses and neonatal infants. Pediatr Dev Pathol 1999;2:215-20.

5) Share JC, Pursley D, Teele RL. Unsuspected hepatic injury in the neonate --diagnosis by ultrasonography. Pediatr Radiol 1990;20:320-2.

6) Fanaroff AA, Martin RJ. Neonatal perinatal medicine disease of the fetus and infant. 6th ed. St. Louis: Mosby, 1997:458-88.

7) Mouratidis B, Antonio G. Sonographic diagnosis of subcapsular liver hematoma mimicking tumor in a neonate. J Clin Ultrasound 2000;28:53-7.

8) Moon SK, Lee TS, Yoon HS. A case of delayed hemorrhage of a subcapsular liver hematoma in a neonate. Korean J Pediatr 2008;51:89-92.

9) Ahn HS, Chang YW, Lee DW, Kwon KH, Yang SB. An incidentally detected hepatic subcapsular hematoma in a very low birth weight newborn: a case report. Cases J 2010;3:32.

10) Anjay MA, Sasidharan CK, Anoop P. Hepatic subcapsular hematoma: two neonates with disparate presentations. Pediatr Neonatol 2012;53:144-6.

11) Son SH, Nam KA, Choi JY, Kim MJ, Seo SS, Kweon JM. One case of subcapsular hematoma with persistent neonatal hyperbilirubinemia. J Korean Soc Neonatol 2001:8:145-9.

12) Lee $J H, I m S A$. Neonatal subcapsular hepatic hematomas presenting as a scrotal wall hematoma. Pediatr Int 2011;53:777-9.

13) Costa S, De Carolis MP, Savarese I, Lacerenza S, Romagnoli C. Hepatic hematoma in a neonate with a high level of alpha-fetoprotein. Eur J Pediatr 2008;167:591-3.

14) Maze A, Lieber MA, Aballi AJ. Neonatal subcapsular hematoma of the liver presenting as an abdominal mass. Report of two cases. Clin Pediatr (Phila) 1979;18:307, 311-2.

15) Im SA, Lim GY. Subcapsular hematoma of the liver in a neonate: case Report. J Korean Radiol Soc 2005;52:41-3

16) Foss K. A case report of a low-birth-weight infant with a subcapsular liver hematoma and spontaneous bowel perforation. Adv Neonatal Care 2004:4:67-78.

17) Mouzard A, Cohen JY, Huault G. Ultrasonography in subcapsular hematomas of the liver in the newborn. Pediatrics 1982;70:1016. 